\title{
23. SEARCH FOR EOLIAN LIPIDS IN THE PLEISTOCENE OFF CAPE BOJADOR AND LIPID GEOCHEMISTRY OF A CRETACEOUS MUDSTONE, DSDP/IPOD LEG 47A ${ }^{1}$
}

\author{
Bernd R. T. Simoneit and Monica A. Mazurek, Institute of Geophysics and Planetary Physics, University of \\ California, Los Angeles, California
}

\begin{abstract}
Pleistocene and Cretaceous sediments from the eastern North Atlantic Ocean off Cape Bojador (Site 397) were analyzed for lipids. Distribution patterns of higher molecular-weight $n$-alkanes and of $n$-fatty acids $>n-\mathrm{C}_{21}$ for sediment assays closely reflected those of terrigenous vascular plants. The detection of dehydroabietic acid and the distributions of the $n$-methylketones also corroborate the influx of terrigenous lipids. The lipids of the Pleistocene samples appear to have an eolian origin.
\end{abstract}

\section{INTRODUCTION}

Eolian dust is carried by the northeast trade winds from the northern continent of Africa and falls over the North Atlantic Ocean (Simoneit et al., 1977; Simoneit, 1977a; Lepple and Brine, 1976). Analyses of the lipids of such dusts indicated that they were of predominantly a higher plant wax derivation (Simoneit, 1977a; Simoneit et al., 1977). The distribution patterns of $n$-alkanes, $n$-fatty acids, and $n$-alcohols in the dust lipids have been correlated with similar homolog distributions in the lipids from sediments in the fallout areas (e.g., Site 138: Simoneit and Eglinton, 1977; Simoneit, 1975; Sites 367 and 369: Simoneit, 1978a). Thus, it is of interest to examine the lipids of other DSDP sediments with potential dust components to determine the areal distribution and depth within the sedimentary column of such eolian input.

Cretaceous black shales and mudstones have been analyzed from many DSDP sites in the Atlantic Ocean, and some of these areas were anoxic basins with high sedimentation rates and a large influx of terrigenous detritus (Simoneit, 1978b). Therefore, it is of interest to determine if for sediments from the northeastern Atlantic Ocean, the analyses of the lipids would allow a distinction to be made between the autochthonous marine and allochthonous terrigenous sources, and if some inferences about the paleoenvironmental conditions of sedimentation could be proposed.

The samples examined here were derived from Site 397 , located on the juncture between the continental rise and slope off Cape Bojador, northwestern Africa $\left(26^{\circ} 50.7^{\prime} \mathrm{N}, 15^{\circ} 10.8^{\prime} \mathrm{W}\right.$; water depth $2900 \mathrm{~m}$ ) (Ryan et al., 1976).

${ }^{1}$ Contribution No. 1783 from Institute of Geophysics and Planetary Physics, University of California, Los Angeles, California

\section{EXPERIMENTAL}

The core samples were freeze-dried and then extracted with toluene and methanol (3:7) in a Soxhlet apparatus ( 300 cycles of solvent change). The extracts for each sample were concentrated on a rotary evaporator, treated with $\mathrm{BF}_{3}$ in methanol to esterify free acids, and then subjected to silica gel thin-layer chromotography (TLC) using methylene chloride as eluent. After development in iodine vapor, the bands corresponding to hydrocarbons and esters with ketones were scraped off the TLC plate and eluted with methylene chloride. These fractions were subjected to gas chromatographic (GC) and mass spectrometric (MS) analyses.

The GC analyses were carried out on a HewlettPackard Model 5830 gas chromatograph using a $30 \mathrm{~m}$ $\times 0.25 \mathrm{~mm}$ glass capillary column wall-coated with $\mathrm{OV}-101$, programmed from 40 to $260^{\circ} \mathrm{C}$ at $4^{\circ} \mathrm{C}$ per minute, then held isothermal for 80 minutes, using $\mathrm{He}$ carrier gas at a flow rate of $2 \mathrm{ml} / \mathrm{min}(30 \mathrm{~cm} / \mathrm{s}$ linear velocity).

The GC/MS analyses were carried out on a Finnigan Model 4000 quadrupole mass spectrometer interfaced directly with a Finnigan Model 9610 gas chromatograph equipped with a $30 \mathrm{~m} \times 0.75 \mathrm{~mm}$ glass capillary column $(\mathrm{J}+\mathrm{W}$, Inc.) which was wall-coated with $0 \mathrm{~V}-101$. The mass spectrometric data were acquired and processed using a Finnigan-Incos Model 2300 data system.

\section{RESULTS AND DISCUSSION}

The sample descriptions and results of the carbon and lipid analyses are given in Table 1. The lipid yields were low and the $n$-fatty acids were present in greater abundance than $n$-alkanes. Ketones were present as minor components only. The distribution diagrams for the $n$-alkanes, $n$-fatty acids, and $n$-methylketones are shown in Figure 1.

The Pleistocene samples from Site 397 contained lipids attributable to a terrigenous origin. The $n$-alka- 
TABLE 1

Sample Description, Carbon Analyses, and Extract Yields for Core Samples Examined

\begin{tabular}{|c|c|c|c|c|c|c|c|c|c|c|c|c|c|c|c|c|}
\hline \multirow{3}{*}{$\begin{array}{c}\text { Sample } \\
\text { (Interval } \\
\text { in } \mathrm{cm} \text { ) }\end{array}$} & \multirow{3}{*}{$\begin{array}{l}\text { Depth } \\
\text { Below } \\
\text { Sea } \\
\text { Bed } \\
(\mathrm{m})\end{array}$} & \multirow[b]{3}{*}{ Lithology } & \multirow{3}{*}{$\begin{array}{c}\text { Geologic } \\
\text { Age }\end{array}$} & \multirow{2}{*}{\multicolumn{3}{|c|}{ Carbon $^{\mathrm{a}}$}} & \multicolumn{10}{|c|}{ Lipids } \\
\hline & & & & & & & \multirow{2}{*}{$\begin{array}{l}\text { Hydro- } \\
\text { carbons } \\
(\mu g / g)\end{array}$} & \multicolumn{2}{|c|}{$n$-alkanes } & \multirow[b]{2}{*}{$\mathrm{Pr} / \mathrm{Ph}$} & \multicolumn{3}{|c|}{$n$-fatty acids } & \multicolumn{3}{|c|}{$n$-methylketones } \\
\hline & & & & $(\%)$ & (\%) & $(\%)$ & & CPI & $\operatorname{Maxima}^{\mathrm{b}}$ & & $(\mu \mathrm{g} / \mathrm{g})$ & CPI & $\operatorname{Maxima}^{\mathrm{b}}$ & $(\mu \mathrm{g} / \mathrm{g})$ & $\mathrm{CPI}$ & $\operatorname{Maxima}^{b}$ \\
\hline $\begin{array}{l}397-2-5, \\
120-150\end{array}$ & 16.3 & $\begin{array}{l}\text { Nannofossil } \\
\text { foraminiferaI } \\
\text { clay ooze }\end{array}$ & Pleistocene & 9.07 & 0.47 & 72 & 2.1 & 1.7 & 23,31 & 1.07 & 5.7 & 5.5 & 16,26 & 0.12 & 1.42 & $17,20,25$ \\
\hline $\begin{array}{l}397-6-3 \\
120-135\end{array}$ & 51.2 & $\begin{array}{l}\text { Nannofossil } \\
\text { foraminiferal } \\
\text { radiolarian } \\
\text { mud }\end{array}$ & Pleistocene & 7.07 & 0.81 & 52 & 0.8 & 1.8 & $17,23,31$ & 1.3 & 3.3 & 6.1 & 16,26 & 0.44 & 2.23 & 17,27 \\
\hline $\begin{array}{l}397 \mathrm{~A}-51-4 \\
100-112\end{array}$ & 1444.0 & $\begin{array}{l}\text { Gray } \\
\text { mudstone }\end{array}$ & $\begin{array}{l}\text { Cretaceous } \\
\text { (Hauterivian) }\end{array}$ & 1.15 & 0.82 & 3 & 2.0 & 2.6 & $17,25 \simeq 27$ & 1.1 & 2.0 & 5.0 & 16,28 & 0.5 & 1.7 & 17,27 \\
\hline
\end{tabular}

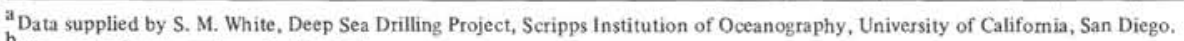

$\mathrm{b}$ The predominant maximum is italicized.

nes of both samples $(397-2-5,120-150 \mathrm{~cm}$, and 397$6-3,120-135 \mathrm{~cm}$ ) exhibit maxima at $n-\mathrm{C}_{23}$ and $n-\mathrm{C}_{31}$, with no carbon number predominance $<n-\mathrm{C}_{26}$ and a strong odd carbon number predominance $>n-\mathrm{C}_{2}$, (cf., Figure 1A, B). This higher molecular weight $n$-alkane distribution is typical of vascular plant wax (Simoneit, $1975,1977 \mathrm{~b})$. The abundance of $n-C_{31}>n-C_{29}$ and $n-\mathrm{C}_{2}$ is similar to grassland and swamp vegetation (i.e.., less forest plants: Cranwell, 1973; Simoneit, (1977b). The $n$-fatty acids of both samples exhibit maxima at $n-\mathrm{C}_{16}$ and $n-\mathrm{C}_{26}$ with a strong even-to-odd carbon number predominance (cf. Figure 1D, E). The homolog distribution $<n-\mathrm{C}_{20}$ is typical of a marine origin (Boon et al., 1975; Simoneit, 1975) and possibly lacustrine derivation (e.g., Simoneit, 1977a, b). The homolog distribution $>n-\mathrm{C}_{21}$ is probably due to higher vascular plants (Hitchcock and Nichols, 1971; Simoneit, 1975, 1977b, c). Dehydroabietic acid (Figure 2A) is present in both samples as a minor component and is the predominant diterpenoid detected. Such diterpenoids are unambiguous marker compounds of terrigenous resinous plants (Simoneit, 1977c). Triterpenoids and steroids are present as minor components only. The terrigenous lipids are derived from eolian input (Simoneit, 1977a; Simoneit and Eglinton, 1977; Simoneit et al., 1977), since no major rivers drain into that geographic area. The lipid distributions of these two samples compare well with similar samples from Site 369 (Simoneit, 1978a).

Sample 397A-51-4, 100-112 cm is of Early Cretaceous age and was deposited in a prodeltaic environment at a rapid accumulation rate (Ryan et al., 1976). The lipid yield of this sample is low. The $n$-alkanes (cf. Figure 1C) exhibit a major maximum at $n-\mathrm{C}_{27}$, with a strong odd-to-even carbon number predominance $>n$ $\mathrm{C}_{22}$, and a minor predominance of $n-\mathrm{C}_{17}$ and $n-\mathrm{C}_{19}$. The higher molecular weight $n$-alkanes $\left(>n-\mathrm{C}_{22}\right)$ are derived from vascular plants (possibly from marsh or sea grasses) and the homologs $<n-C_{20}$ are of an autochthonous origin. The pristane to phytane ratio $(\mathrm{Pr} /$ $\mathrm{Ph})$ is 1.1, which is a value on the borderline of oxic versus anoxic paleoenvironmental conditions (Didyk et al., 1978). The presence of fine laminations and plant debris, with the absence of bottom-dwelling invertebrates and burrows (Ryan et al., 1976), corrobo- rate the data above. The $n$-fatty acids exhibit a bimodal distribution (cf. Figure $1 \mathrm{~F}$ ) with maxima at $n-\mathrm{C}_{16}$ and $n-\mathrm{C}_{28}$ and a strong even-to-odd carbon number predominance. The homolog distribution $>n-C_{21}$ is typical of a higher plant origin and the homologs < $n-\mathrm{C}_{20}$ are due to an autochthonous marine origin. Only a trace of dehydroabietic acid (Figure 2A) is present indicating a minor influx of resinous plant detritus.

Ketones in the lipids of these three samples were analyzed. The predominant ketones consist of $6,10,14-$ trimethylpentadecan-2-one (Figure 2B) and lesser amounts of 6,10-dimethylundecan-2-one and $n$-methylketones, $\mathrm{C}_{n} \mathrm{H}_{2 n} \mathrm{O}$, ranging from $n=12$ to 31 (cf. Figure $1 \mathrm{G}$ to I). The $n$-methylketones exhibit a strong even-to-odd carbon number predominance and maxima at $\mathrm{C}_{17}$ and $\mathrm{C}_{25}$ or $\mathrm{C}_{27}$. These $n$-methylketones reflect a terrigenous origin and their distributions are analogous to those for samples from the Black Sea (Simoneit, 1978c). The $n$-methylketones are probably derived from $n$-fatty acids by microbial $\beta$-oxidation or by microbial oxidation of $n$-alkanes (Arpino, 1973). The relatively large concentration of the isoprenoidal ketones versus the $n$-methylketones may indicate a greater autochthonous productivity, since the precursor for the isoprenoids is phytol from chlorophyll (Simoneit, 1973). Triterpenoidal ketones are present as trace components only and triterpenoidal acids are not detectable.

Other compounds that have been identified consist of diterpenoidal hydrocarbons, sesquiterpenoidal hydrocarbons, and minor contaminants. Perylene was not detectable. Samples 397-2-5, 120-150 cm and 397-6-3, $120-135 \mathrm{~cm}$ contain minor amounts of dehydroabietin (Figure 2C) and retene (Figure 2D). Sample 397A-514 , 100-112 cm contains significant amounts of di- and sesquiterpenoids (cf., Figure 1C). The major analog is retene (Figure 2D), with lesser amounts of dehydroabietane (Figure 2E), simonellite (Figure 2F), and cadalene (Figure 2G). The minor components that have been detected are dehydroabietin (Figure 2C), iosene dihydrokaurene (Figure $2 \mathrm{H}$ ), a sesquiterpene $\left(\mathrm{C}_{15} \mathrm{H}_{20}\right)$, two isomers of trimethylnaphthalene $\left(\mathrm{C}_{13} \mathrm{H}_{14}\right)$, two isomers of normethyldehydrocadinene $\left(\mathrm{C}_{14} \mathrm{H}_{20}\right)$, and phenanthrene or anthracene $\left(\mathrm{C}_{14} \mathrm{H}_{10}\right)$. These hydrocarbons are diagenetic products of di- and sesquiter- 

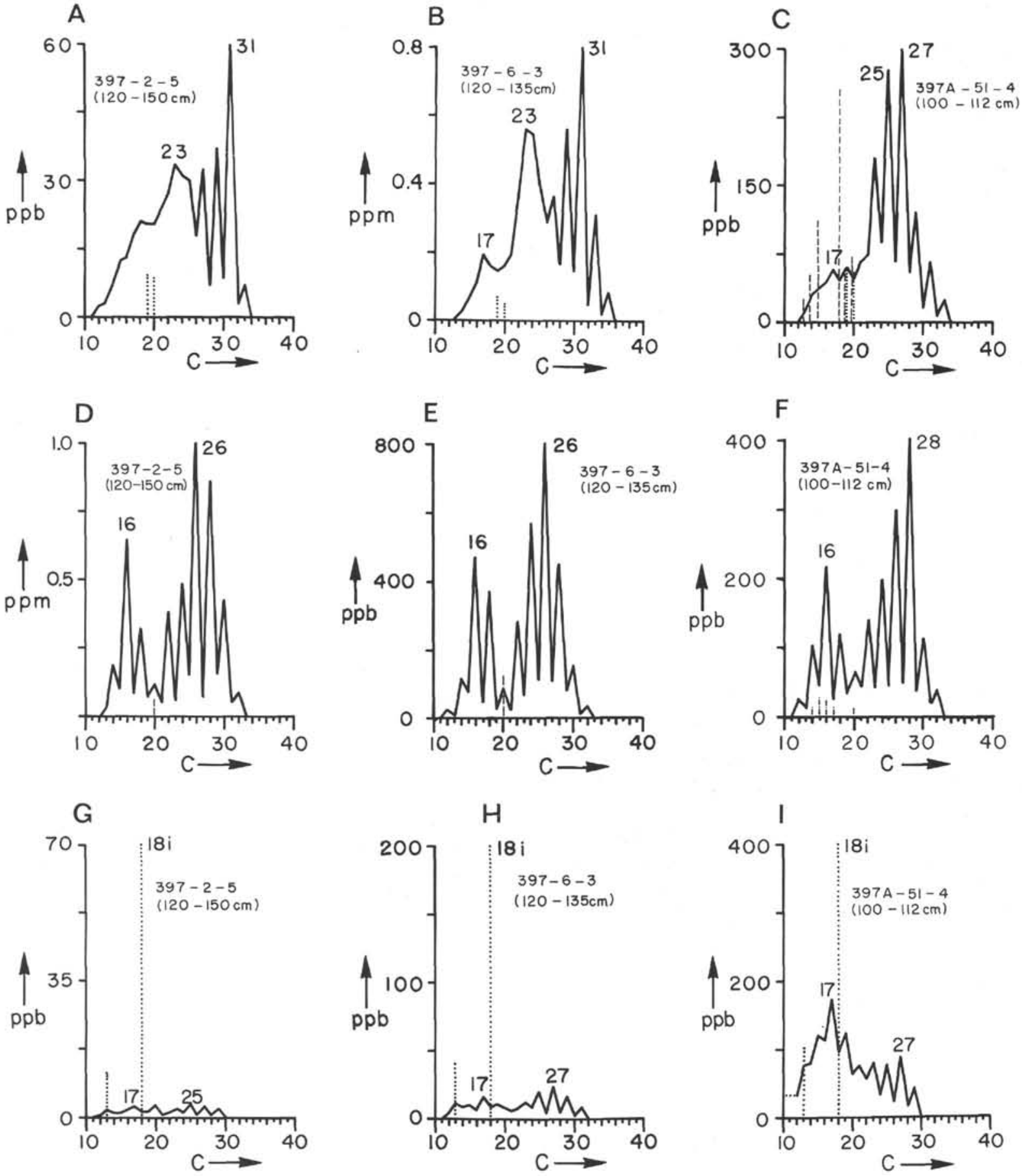

Figure 1. Distribution diagrams for $\mathrm{n}$-alkanes in $A$ to $C(\ldots \ldots=$ isoprenoids, height of line indicates approximate concentration); $\mathrm{n}$-fatty acids in $D$ to $F(\cdots \cdots=$ isoprenoids, $-\cdots=$ diterpenoids, $-\cdot-\cdot-=$ anteiso); $\mathrm{n}-$ methylketones in $G$ to $I$ ( $\cdots \cdots=$ isoprenoids).

penoids from resinous higher plants (Simoneit, 1977c), as is the case for the dehydroabietic acid in the fatty acid fractions. Cadalene has previously been identified in petroleum (Bendoraitis, 1974) but not in sediments. Contamination from various plasticizers was minor and consists of butyl and octyl phthalates.

\section{CONCLUSIONS}

Evidence of eolian dust contribution to deep-sea sediments can be seen in the constituent mixture of lipids extracted from Pleistocene sediments. In the case of Samples 397-2-5, 120-150 cm, and 397-6-5, 120-135 
<smiles>CC(C)c1ccc2c(c1)CCC1O[C@](C)(C(=O)O)CCC[C@@]21C</smiles>

A Dehydroabietic acid, $\mathrm{C}_{20} \mathrm{H}_{28} \mathrm{O}_{2}$

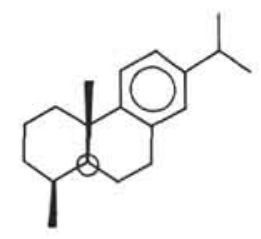

C Dehydroabietin, $\mathrm{C}_{19} \mathrm{H}_{28}$

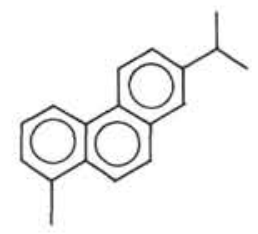

D Retene, $\mathrm{C}_{18} \mathrm{H}_{18}$

$$
\text { E Dehydro }
$$
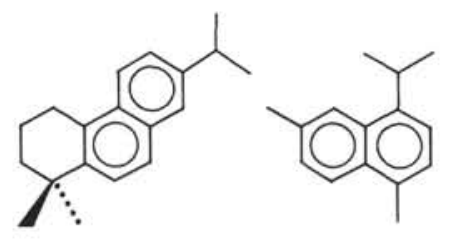

F Simonellite, $\mathrm{C}_{19} \mathrm{H}_{24}$

G Cadalene, $\mathrm{C}_{15} \mathrm{H}_{18}$

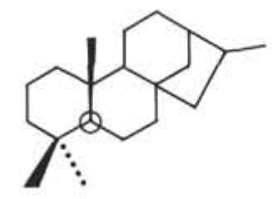

$\mathrm{H}$ losene, $\mathrm{C}_{20} \mathrm{H}_{34}$

Figure 2. Chemical structures of Site 397 lipid components.

$\mathrm{cm}$, the appearance of $n$-alkane maxima at $n-\mathrm{C}_{23}$ and $n-\mathrm{C}_{31}$ along with a definite odd-carbon number predominance $>n-\mathrm{C}_{27}$ clearly mimic the higher molecular weight compound distribution of vascular plant wax. Moreover, contributions from grassland and swamp detritus can be inferred from the preponderance of $n$ - $\mathrm{C}_{31}$ over $n-\mathrm{C}_{29}$ and $n-\mathrm{C}_{27}$ homologs. Further support of terrestrial derivation can be drawn from the bimodal distribution of $n$-fatty acids where both lacustrine and/ or marine $\left(<n-\mathrm{C}_{20}\right)$ and allochthonous terrigenous ( $>$ $n-\mathrm{C}_{21}$ ) components are detected. Diterpenoids are observed as minor components and are also suggestive of a higher plant origin, resinous vegetation in particular. Importantly, the origin of these terrigenous lipids is presumed to be from eolian contribution rather than from potamic deposition since no major rivers feed into this geographic locale.

Distributions observed from the Cretaceous sample (397A-51-5, 100-112 cm) also suggest a terrigenous origin. In the case of $n$-alkanes, the predominance of odd-to-even $>n-\mathrm{C}_{21}$ with the major maximum at $n-C_{27}$ reflect higher plant derivation. Again, the bimodal fatty acid distribution with maxima at $n-\mathrm{C}_{16}$ and $n-C_{28}$ shows the duality of autochthonous and allochthonous sources. Unlike the Pleistocene samples, only a trace of dehydroabietic acid was detected.

Homologous $n$-methylketones ranging from $n-\mathrm{C}_{12}$ to $n$ - $C_{31}$ show bimodal maxima at $C_{17}$ and at $C_{25}$ or $C_{27}$, and may be ascribed in part to degradation of terrigenous $n$-alkane or $n$-fatty acid precursors by microbial oxidation. However, the predominant isoprenoidal ke- tones are probably derived from the phytyl side chain of chlorophyll and also indicate an autochthonous lipid contribution.

\section{ACKNOWLEDGMENTS}

We thank the National Science Foundation for making the core samples available, and E. Ruth for assistance with GC/MS data acquisition. Partial financial assistance from the National Science Foundation (Grant No. OCE 76-21506) and from the Energy Research and Development Administration [Grant E(or-3)-34 P.A. 134] is gratefully acknowledged. We thank Dr. Shmuel Brenner and Dr. Ansis Kaneps for the review of the manuscript.

\section{REFERENCES}

Arpino, P., 1973. Les lipides des sédiments lacustres éoc̀enes, Thèse, l'Universite Louis Pasteur de Strasbourg, France.

Bendoraitis, J. G., 1974. Hydrocarbons of biogenic origin in petroleum - aromatic triterpenes and bicyclic sesquiterpenes. In Tissot, B. and Bienner, F. (Eds.), Advances in organic geochemistry 1973: Paris (Editions Technip), p. 209-224.

Boon, J. J., deLeeuw, J. W., and Schenck, P. A., 1975. Organic geochemistry of Walvis Bay diatomaceous ooze. I. Occurrence and significance of the fatty acids, Geochim. Cosmochim. Acta, v. 39, p. 1559-1565.

Cranwell, P. A., 1973. Chain-length distribution of $n$-alkanes from lake sediment in relation to post-glacial environmental change, Freshwater Biol., v. 3, p. 259-265.

Didyk, B. M., Simoneit, B. R. T., Brassell, S. C., and Eglinton, G., 1978. Geochemical indicators of paleoenvironmental conditions of sedimentation, Nature, v. 272, p. 216-222.

Hitchcock, C. and Nichols, B. W., 1971. Plant lipid biochemistry: London (Academic Press).

Lepple, F. K. and Brine, C. J., 1976. Organic constituents in eolian dust and surface sediments from northwest Africa, J. Geophys. Res., v. 81, p. 1141-1147.

Ryan, W. B. F., von Rad, U., Arthur, M., McCoy, F., Sarnthein, M., Weser, O., Lopatin, B. G., Cita, M. B., Lutze, G. F., Čepek, P., Wind, F., Hamilton, N., Mountain, G., Whelan, J., Cornford, C., and Banyra, L., 1976. Passive continental margin, Geotimes, v. 21, p. 21-24.

Simoneit, B. R. T., 1973. Appendix I. Identification of isoprenoidal ketones in Deep Sea Drilling Project core samples and their geochemical significance. In Burns, R. E., Andrews, et al., Initial Reports of the Deep Sea Drilling Project, v. 21: Washington (U.S. Government Printing Office), p. 909-923.

1975. Sources of organic matter in oceanic sediments, Ph.D. Thesis. University of Bristol, England.

1977a. Organic Matter in Eolian Dusts Over the Atlantic Ocean, Proceedings of Symposium on Concepts in Marine Organic Chemistry, Mar. Chem., v. 5, p. 443-464.

1977b. The Black Sea, a sink for terrigenous lipids, Deep-Sea Res., v. 24 , p. 813-830.

1977c. Diterpenoid compounds and other lipids in deep-sea sediments and their geochemical significance, Geochim. Cosmochim. Acta, v. 41, p. 463-476.

1978. Leg 41 sediment lipids - Search for eolian organic matter in Recent samples and examination of a black shale. In Lancelot, Y., Seibold, E., et al., Initial 
Reports of the Deep Sea Drilling Project, v. 41: Washington (U.S. Government Printing Office), p. 855-858.

$1978 \mathrm{~b}$. Organic Geochemistry of the Shales and Sapropels of the Cretaceous Atlantic, 8th Internatl. Meeting on Organic Geochemistry, 8-13 May 1977, Moscow.

1978c. Organic geochemistry of terrigenous muds and various shales from the Black Sea, DSDP Leg 42B. In Ross, D., Neprochnov, Y., et al., Initial Reports of the
Deep Sea Drilling Project, v. 42, Part 2: Washington (U.S. Government Printing Office), p. 749-754).

Simoneit, B. R. T. and Eglinton, G., 1977. Organic matter of eolian dust and its input to marine sediments. In Campos, R. and Goni, J. (Eds.), Advances in organic geochemistry 1975: Madrid (ENADIMSA), p. 415-430.

Simoneit, B. R. T., Chester, R., and Eglinton, G., 1977. Biogenic lipids in particulates from the lower atmosphere over the Eastern Atlantic, Nature, v. 267, p. 682-685. 